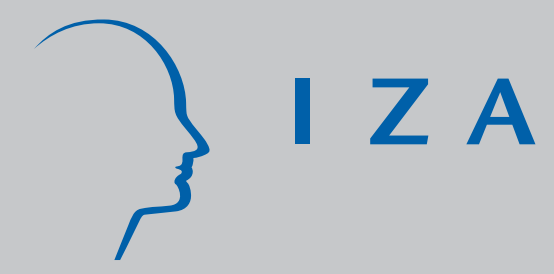

IZA DP No. 1409

Private Returns to Human Capital over Transition: A Case Study of Belarus

Francesco Pastore

Alina Verashchagina

November 2004 


\title{
Private Returns to Human Capital over Transition: A Case Study of Belarus
}

\author{
Francesco Pastore \\ Seconda Università di Napoli \\ and IZA Bonn
}

Alina Verashchagina

Belarusian National Technical University

\author{
Discussion Paper No. 1409 \\ November 2004
}

\author{
IZA \\ P.O. Box 7240 \\ 53072 Bonn \\ Germany \\ Phone: +49-228-3894-0 \\ Fax: +49-228-3894-180 \\ Email: iza@iza.org
}

\begin{abstract}
Any opinions expressed here are those of the author(s) and not those of the institute. Research disseminated by IZA may include views on policy, but the institute itself takes no institutional policy positions.

The Institute for the Study of Labor (IZA) in Bonn is a local and virtual international research center and a place of communication between science, politics and business. IZA is an independent nonprofit company supported by Deutsche Post World Net. The center is associated with the University of Bonn and offers a stimulating research environment through its research networks, research support, and visitors and doctoral programs. IZA engages in (i) original and internationally competitive research in all fields of labor economics, (ii) development of policy concepts, and (iii) dissemination of research results and concepts to the interested public.
\end{abstract}

IZA Discussion Papers often represent preliminary work and are circulated to encourage discussion. Citation of such a paper should account for its provisional character. A revised version may be available directly from the author. 
IZA Discussion Paper No. 1409

November 2004

\section{ABSTRACT}

\section{Private Returns to Human Capital over Transition: A Case Study of Belarus}

The gradualist approach to economic transition in Belarus would contribute to form the a priori expectation that the rate of return to education is low and the earnings profile by work experience flat, like they supposedly were under central-planning. However, the first available estimates of Mincerian earnings equations based on the Belarusian Household Survey on Incomes and Expenditure suggest that the skill payoff was high in 1996, at about $10.1 \%$ per year, and stable. The return to one year of work experience is also high at $5 \%$. This result maintains also after controlling for sample selection bias, despite a general reduction in the annual rate of return to education by about $20-30 \%$. Though, it is ambiguous whether the high-skill payoff is the consequence of market forces coming into play or of policy decisions, considering the pervasive role of the state in the process of wage determination.

JEL Classification: J31, P52

Keywords: educational economics, returns to human capital, economic transition, Belarus

Corresponding author:

Francesco Pastore

Seconda Università di Napoli

Piazza Matteotti

81055, Santa Maria Capua Vetere (Caserta)

Italy

Email: fpastore@unina.it 


\section{Introduction}

This research work provides the first available evidence on the returns to education in Belarus ${ }^{1}$. Belarus is an interesting case study for the specific transition path followed. After a period of fast reforms in the early 1990s, which led to price (but not wage) liberalisation, Belarus has been, perhaps, the least reformed of the transition economies in Eastern Europe and in the CIS. In fact, though being the target of recent interventions, which led price growth to go down from three to two digits, macroeconomic stabilisation is still far from being achieved. Privatisation is progressing very slowly. Trade liberalisation is not implemented yet and the State exerts a strict control on the labour market.

This situation provides a unique testing ground of many hypotheses developed in the economic transition literature about the size of the increase in the returns to education, and about the determinants of such an increase. How sizeable were returns to education in the planned economies? What role did privatisation play? And how important were price and trade liberalisation? More generally, does the speed of transition matter when looking at the evolution of returns to education over transition?

To form an a priori expectation on these issues is not an easy task. On the one hand, this country has adopted a very slow approach to economic reforms, which suggests that the incentive for human capital accumulation has been low. In fact, the state sector still represents an important part of the overall output. On the other hand, Belarus has always been one of the Commonwealth of Independent States (CIS) with the highest ranks of the Human Development Index (UNDP, 2003), essentially because

\footnotetext{
${ }^{1}$ In fact, there is not any specific study available on this country and Belarus is not even included in any of the most comprehensive analyses on the returns to education in transition countries (Newell and Reilly, 1999; Svejnar, 1999; Brainerd, 2000; Trostel, Walker and Woolley, 2002).
} 
of the high level of human capital accumulation. This would suggest that the returns to such type of investment be high. Then, the questions arises of what role human capital played in shaping economic transition in Belarus and vice versa of how returns to education were affected by the on-going economic transformation.

Large evidence relative to various Central and Eastern European Countries (CEECs) as well as countries in the CIS both in the pre- and post-transition era suggests that the increase in the returns to education was noticeable, but slower than expected (reaching 4-5\% on average in the mid-1990s, according to Newell and Reilly, 1999), while wage inequality was often driven by the increased complexity of the production structure (structural change). Conversely, generic and, even more so, job-specific work experience exhibits a lower return than in Western countries, also when combined with high education attainments (Orazem and Vodopivec, 1997; Newell and Reilly, 1999; Svejnar, 1999; Sabirianova, 2003). In her comprehensive study on returns to education in several CEE and CIS economies, Brainerd (2000) found a lager increase in the returns to education than that found in Newell and Reilly (1999), but mixed evidence on returns to work experience.

Estimates of Mincerian earnings functions based on the 1996 and 2001 waves of the Belarusian Household Survey of Incomes and Expenditure (BHSIE) partly confirm the above expectations, though with some surprises. Despite the gradual pace of reforms, the rate of return to each year of schooling is not lower than in many other transition countries, moving from 10.1 to $10.7 \%$ of the main wage for workers holding a University degree. Work experience provides workers with a further annual increase in wages by $5 \%$, a premium that remained stable over the considered years. 
This is quite a high skill payoff. How to interpret this result? It might suggest that a market for human capital is in place. Though, it is difficult to say whether this high educational premium is a consequence of decentralised mechanisms of resource allocation or, which is also likely, considering the state control on the system of wage determination, of a government policy in favour of high skill workers to increase their productivity and, in the meantime, to maintain consensus. Starting from the mid-1990s, the country experienced increased competition from abroad, which could not be hindered via the usual mechanism of price control, partly abandoned already in the early 1990s. This pushed the government to look for ways to increase the competitiveness of manufacturing products without giving up state ownership. One way to do this might have been to use the wage grid to provide highly educated and experienced workers with higher wages. In the meantime, to correct the regressive nature of the wage distribution, the government provided compensatory in-kind payments and subsidies to low skill workers. This pressure on wages, triggered also by the price increase of foreign goods, could also explain the high inflation rate the country continues to experience.

The structure of the paper is the following. Section one provides some basic facts about returns to education in transition countries and analyses the forces affecting the wage distribution over transition. Section two focuses on the Mincerian approach. Section three introduces data set and variables used for the analysis. Section four analyses the econometric results, including those based on procedures to correct for selection bias, while section five puts the results in perspective. Some concluding remarks follow. 


\section{Returns to education in transition countries}

\subsection{Wages under the central-planning system}

Under central planning, the Government used to set wages of workers (almost) entirely employed in the state sector. It did so by imposing a centrally determined wage grid. The criteria followed obeyed to political and equity considerations, rather than to efficiency criteria and economic calculus ${ }^{2}$. Wage equalisation across individuals, regions and sectors was a constant target of the central planner.

Moreover, in the former Soviet Union some specific groups and sectors used to receive special wage premia. This is, for instance, the case of individuals serving in the army and, more importantly, of blue-collar workers, employed in the mining or manufacturing sectors. As a consequence, despite the difference in educational levels, manual workers fared relatively well compared to their counterparts employed, for instance, in the public service sector, especially health, education and culture.

Where wages in the FSU compressed or dispersed? How did the returns to education and work experience compare to Western standards? The literature is not unanimous, also because the evidence is still scarce. In the first systematic study of income and wage inequality in former communist countries, Atkinson and Mickelwright (1992) argued that, beyond the communist ideology, inequality was not low, that the returns to education were at least as high and the returns to work experience were as concave as in the West. Similar conclusions are reached in Katz (1999) and Munich, Svejnar and Terrell (2002). Conversely, Benitez-Silva and Cheidvasser (2000) claim

\footnotetext{
${ }^{2}$ This statement is based on the idea that market criteria existing in Western countries are the benchmark to evaluate efficiency also in former Socialist economies. However, this assumption does not necessarily hold true and equity can coincide with efficiency criteria: if wages are low and the production is labour intensive (Kornai, 1992), it could be rational to pay manual work the same as work with a higher intellectual content. As a matter of fact, many studies and official documents suggest that manual work was much on demand in the FSU.
} 
that returns to education in Russia were much lower. These authors also found that the returns to education are reducing, not increasing over transition, causing a dramatic migration of high-skilled specialists abroad.

\subsection{Shifts in labour demand and supply by skill in the early transition}

How strong and persistent was the egalitarian inheritance? How much "high" were the rates of return to human capital under central planning? What are the effects of economic transition on the distribution of wages and on the returns to education? Should these last reduce or increase over transition?

As suggested in Svejnar (1999, p. 2835) two possible routes can be taken when attempting to predict the return to investment in human capital in transition countries. The first one would suggest that it should explode, as market mechanisms are supposed to wash away the egalitarian emphasis of communism. The opposite one implies that it should fall, as the "obsolete human capital" may be not very useful in the new economic environment. Various intermediate hypotheses are possible, such as the returns to general and academic education should increase, especially for young people, whereas the returns to work experience and tenure should be reduced.

In fact, various forces affected the market for human capital over transition. On the demand side, a skill biased technical change, adopted also defensively to deal with international competition, should tend the return to education to increase (Aghion and Commander, 1999; Sabirianova, 2003). On the supply side, the high and remarkably increasing share of workers with high levels of human capital in transition countries 
could have reduced the skill premium if one thinks in static terms ${ }^{3}$. However, within the context of models with endogenous technical change, a sufficiently sizeable and continuous increase in the supply of human capital could accelerate the move towards skill-intensive productions, causing a further increase in the skill premium. The overall effect of shifts in demand for and supply of skills depends on their relative size and might differ across countries also according to the institutional framework in place.

Are there transition specific factors at work? Orazem and Vodopivec (1997), Aghion and Commander (1999) and Sabirianova (2003) point out three main specific forces. First is the removal of the government's power to set wages, which supposedly prevented the emergence of high returns to education under central planning ${ }^{4}$. Second, there was a dramatic shift in the composition of final demand for goods from low skill intensive heavy manufacturing and agriculture to light manufacturing and service industries. This implies an upward wage pressure in favour of high skill labour and of women, since many industries specialised in consumption goods are generally femaledominated. Third, putting an end to the planned economy implies a short-term increase in the level of uncertainty of any economic activity, which creates the demand for high skill workers able to bear and control for risk.

As Newell and Reilly (1999) put it forward in their study of the wage distribution in nine transition countries, there is extensive evidence to say that the private rate of return to a year of education in the centrally planned economies was relatively low by international standards. In general, their study provided estimates of about $2 \%$ in the

\footnotetext{
${ }^{3}$ The share of workers with high secondary and with tertiary education was already high in the CEECs and in the CIS (also by Western standards) at the initial stage of economic transition and conspicuously further increased in the last two decades. The high share of workers with high educational qualification in the presence of low returns to education under socialism should not seem odd. In fact, as noted in Orazem and Vodopivec (1997), the direct and opportunity costs of high education under socialism were low: while not paying fees, students received scholarships and had little to lose from postponing the beginning of their working life.

${ }^{4}$ Nonetheless, as Brainerd (2000) notes, wage policy hindered wage dispersion, especially in CEECs.
} 
pre-transition period and between $4 \%$ and $5 \%$ over the first half of the 1990 s. These figures give some indication of the extent to which human capital was undervalued under central planning. Newell and Reilly (1999) take as term of reference the estimates provided by Psacharopoulos (1994) for a large sample of market economies. They ranged in value from between $6.6 \%$ for the high and $11.2 \%$ for the low per capita income countries. The average estimates for market economies in the lower-middle per capita income range, the one in which most socialist economies would fall, recorded over $11 \%$ increase in monthly wages for each additional year of education.

Nonetheless, as a strand of literature (see, for instance, Rutkowski, 1996; Newell and Reilly, 1999; Svejnar, 1999; Brainerd, 2000; Trostel, Walker and Woolley, 2002, Table 4) has found, the human capital payoff, as measured within the context of augmented Mincerian earning equations, has increased almost constantly and universally, though at a slow pace, in the second half of the $1990 \mathrm{~s}^{5}$.

\section{The modelling strategy}

The modelling strategy adopted in this paper is standard, since the main aim is to provide detailed and internationally comparable evidence on returns to investment in human capital in Belarus, a country largely neglected in the literature. The Mincerian approach to estimating the returns to human capital was taken as a basis. The starting

\footnotetext{
${ }^{5}$ A slightly different picture emerges from other contributions. In their study of the returns to education in 28 countries over the period from 1985 to 1995 based on a common questionnaire, Trostel et al. (2002, Table 2) find that transition countries have rates of returns to education that differ remarkably from one another. Two groups of countries can be disentangled: on the one hand, Bulgaria, Czechoslovakia, the Czech and the Slovak republic and Russia exhibit a coefficient for years of schooling ranging between 3.1 and 5.2; on the other hand, Hungary, Latvia, Poland and Slovenia exhibit a coefficient for years of schooling ranging between 6.7 and 8.0. The relevant coefficient in the pooled regression including all the countries in the sample equals 4.8. Nonetheless, all the countries exhibit rates of returns that are lower than in the least developed countries, such as the Philippines (11.3). Brainerd (2000) focused on several CEE and CIS economies and found a generalised and sizeable increase in the returns to education, though returns to education increased more in CIS than in CEE economies. The results relative to the returns to work experience were mixed and did not show any clear pattern.
} 
point is the equilibrium condition of the basic human capital model, in which the present value of the (expected) income in a given year is equal to the cost of investment. It can be proven that the internal rate of return to schooling can be then approximated by the difference in the logarithm of wages between leaving education at a given year and that obtainable leaving it in the previous year. More generally, the augmented version of the Mincerian specification of the earnings equation is:

$$
\ln w_{i}=\mathbf{X}_{\mathbf{i}} \boldsymbol{\beta}+r s_{i}+\delta x_{i}+\gamma x_{i}^{2}+u_{i}
$$

where $w_{i}$ is monthly earnings for an individual $i, s_{i}$ represents a measure of his schooling, $x_{i}$ is a measure of work experience, $\mathbf{X}_{\mathbf{i}}$ is a set of other variables assumed to affect earnings, and $u_{i}$ is a disturbance term representing other forces which may not be explicitly measured, assumed independent of $\mathbf{X i}$ and si. Note that work experience is included as a quadratic term to capture the concavity of the earnings profile. $r$ can be considered the private financial return to schooling as well as being the proportionate effect on wages of an increment to $s$.

The above earnings function is in fact a log-linear transformation of an exponential function and can be estimated by OLS. The coefficients have a semi-elasticity interpretation. They measure the ceteris paribus percentage change in the dependent variable for any unit change in any independent variable ${ }^{6}$.

\section{The data set}

\footnotetext{
${ }^{6}$ When the regressor is a continuous variable, such as years of work experience, the elasticity at the mean of the covariates, namely the percentage change in the regressand for a percentage change in the regressor, can be computed multiplying the coefficient by the mean of the regressor: $\beta \bar{X}$. In the case of independent dummy variables, like levels of education attainment, the semi-elasticity interpretation is flawed and, following Halvorsen and Palmquist (1980), it should be computed as: $\left(e^{\beta}-1\right) * 100$. This formula measures the percentage change in the median wage, which is less affected by outliers. Nonetheless, many authors interpret also the estimated coefficients of dummy variables directly as semi-elasticity. This is acceptable when the estimated coefficient is sufficiently close to zero.
} 
The econometric part of this paper is based on the 1996 and 2001 waves of the BHSIE, which started in 1995. With about 5,000 households interviewed every year, it represents the most reliable and comprehensive source of micro-data in the country ${ }^{7}$.

Following Clark (2003), we distinguish different types of earnings, the natural logarithm of which represents the dependent variables of interest in the estimates. Type one is the net monthly wage from the main job (Wage1). Type two includes various subsidies and in-kind payments from the main job, apart from the wage (Wage ${ }^{*}$ ). Type three includes earnings and other monies from secondary jobs and entrepreneurial activities (Wage2). Type four includes all sources of labour income (Wage3). A more detailed definition of these and other variables is contained in Table A1 of Appendix I.

These different types of earnings are used to capture the ability of high skill workers to implement complex strategies to increase their income in an economic environment where the wage from the main job is insufficient to survive. Secondary jobs and entrepreneurial activities often provide the mean to increase earnings, especially for skilled workers. We expect, therefore, that the type one, three and four of wages be positively dependent on educational attainment. In the meantime, we expect that subsidies and in-kind payments (Wage $1 *$ ) work as a compensation mechanism used by state firms to support low-wage workers ${ }^{8}$.

Minor changes to the questionnaire have been imposed over the years under consideration. The main difference between 1996 and 2001 refers in fact to the

\footnotetext{
7 The available release of the BHSIE does not include such variables as firms' ownership, industry, hours of work. We believe that these variables do not considerably affect returns to education, due respectively to the lowest share of private firms, alongside with the pervasive state control on the mechanism of wage determination and the practice of measuring wages on a monthly, not on an hourly basis.

${ }^{8}$ This hypothesis is slightly different from that by Clark (2003) who assumes that also other payments related to the main job are positively related to educational levels.
} 
educational variable. In 1996, respondents are asked to declare their years of school attendance up to general secondary school and their upper educational qualification separately. In 2001, respondents provide information on educational attainment (levels of education) in one single question. Some changes in the composition of employment by educational levels are difficult to understand.

Table 1 documents a conspicuous reduction in the number of workers with vocational secondary education and increase in the number of employed workers with specialised secondary education. This could be due to the changed definition of secondary education in the two point interviews. Remarkable is also the reduction in the number of people with compulsory education. Appendix II provides a short description of the educational system in Belarus.

[Table 1 about here]

\section{Results}

\subsection{Average wages}

Table 2 informs on the distribution of unconditional average monthly wages by educational qualification for every definition of labour incomes. They show that in both years earnings are positively related to the educational level of individuals, though this relationship is weaker in the case of Wage ${ }^{*}$ and Wage 2 . The reason could be the more progressive nature of subsidies and in-kind payments (Wage $\left.1^{*}\right)$. As suggested in Vaneev, Gurskiy and Kisel (2001), these sources of income tend to correct the regressive nature of labour incomes, providing financial subsidies and compensations to 
low-wage workers ${ }^{9}$. Pensions and other subsidies are attributed according to the same logic. In 2001 secondary job holding (Wage2) provides a much higher skill premium than in 1996.

Unreported calculations show that this result holds for both men and women. Worth noting is that, similar to OECD countries (Psacharopoulos, 1994), the payoff to high education is the highest for women.

Already in the middle of the decade, workers with a university degree received remarkably higher wages from their main job, about two and a half times that of their colleagues with compulsory education or below. This is quite a high skill payoff.

In 1996, high secondary education gave a wage premium of between 50 and $80 \%$ in terms of incomes from the main job. As expected, workers with technical fare better than those with vocational or general secondary education. Vocational education provides a final certificate, which gives access to manual jobs with some skill content, whereas general secondary school is just an intermediate step to obtain a university degree.

[Table 2 about here]

\subsection{Basic earnings equations}

\footnotetext{
${ }^{9}$ In Belarus, tariff wages in the budget sector, representing about $80 \%$ of output, are determined on the basis of a tariffs scale (tarifnaya setka), a tariff rate of the first grade (tarifnaya stavka pervogo razryada), a tariff qualification guide (tarifno-kvalifikacionnyi spravochnik). The tariffs scale is a system of coefficients measuring the ratio of the wage of each class to the lowest one (so-called first grade). The tariff qualification guide contains detailed characteristics of professions and types of labour. It allows defining the rank of every type of job. There is also an over-tariff part of wages in the budget sector. It implies premiums and additional payments, which depend on productivity, budget allowances and so on. The tariff scale was continuously revised after 1992, mainly to correct for inflation. The current tariff scale includes 28 classes, which already implies wide earnings dispersion. The ratio between the highest and the lowest ranks equals 8.3, however, the lowest 9 classes are given additional subsidies from the state. Taking them into account the ratio between the highest and the lowest class becomes 5.03. The growth rate of the coefficients from the $1^{\text {st }}$ to the $4^{\text {th }}$ class equals 1.16 . For the $5^{\text {th }}$ and the $6^{\text {th }}$ class it becomes 1.10 . From the $7^{\text {th }}$ to the $28^{\text {th }}$ it is 1.07 . Therefore, although adjusted by a pervasive system of subsidies in favour of workers in the lowest ranks, the tariff grid has a slightly regressive nature (Vaneev et al., 2001).
} 
Until now unconditional means only were considered. Table 3 provides estimates of basic earnings equations for all types of income, using educational qualifications and work experience, also in quadratic term, as independent variables.

The estimates relative to the wage from the main job (Wage1) and the overall labour income (Wage3) are more satisfactory (the Adj.- $\mathrm{R}^{2}$ equals 0.15 ) than those relative to the other two sources of labour income (Wage ${ }^{*}$ and Wage2), which confirms the impression that other sources of income depend on criteria different from human capital attainment. Subsidies, for instance, might have redistributive purposes.

In 1996 , the annual rate of return to post-compulsory education was $12.6 \%$ for those with a university degree, which requires on average seven additional years compared to compulsory education ${ }^{10}$. Overall, university education seems to provide a much higher payoff than in other transition countries (Newell and Reilly, 1999), but comparable to that of low-income countries (Psacharopoulos, 1994).

The annual rate of return to technical secondary school, which requires four additional years after compulsory education, was $14 \%$. For vocational (three additional years) and general secondary (two additional years) education it was $10 \%$ and $14.5 \%$, respectively. This suggests that the reward to high secondary school is higher than that to tertiary education, as one would expect assuming that the marginal rate of return to education is decreasing with education.

By the same token, obtaining a University degree compared to holding a secondary school diploma provides a lower annual rate of return, amounting to 11 and $11.8 \%$ in

\footnotetext{
${ }^{10}$ This figure is obtained dividing the coefficient for university education $\left(\beta_{u}\right)$ by the seven years that are necessary on average to obtain a university degree after finishing compulsory education $\left(Y_{u}-Y_{c}\right): r=\frac{\beta_{u}}{Y_{u}-Y_{c}}$. Multiplying this value by 100 gives the percentage change for every year of additional education.
} 
the case of individuals holding a technical and general secondary education diploma, respectively ${ }^{11}$. These results hold approximately true also in the case when one considers the overall labour income (Wage3), which shows very similar coefficients.

The estimates relative to 2001 confirm the expectation of an increase in the skill payoff, up to $13.3 \%$. The picture relative to other sources of income in column two and three in 2001 is only slightly different from that relative to the same sources of income in 1996.

The returns to every year of work experience in terms of wages from the main job are quite high and stable over time, at about 5\% per year. Moreover, despite being concave like in other countries, they show only very low decreasing returns and reach their maximum after 25 years. This is a high premium to seniority also compared to other CEECs, a premium similar only to such CIS countries like Kyrgyzstan and Ukraine, where transition was very gradual ${ }^{12}$.

Also in the case of work experience, other sources of labour income tend to act as a compensating mechanism for low-wage workers. Wage ${ }^{*}$ seems to be independent of work experience, while Wage 2 and Wage 3 are affected only to a minor extent by work experience. A similar conclusion applies to 2001.

[Table 3 about here]

\subsection{Augmented earnings equations}

$$
{ }^{11} \text { The formula becomes: } r=\frac{\beta_{u}-\beta_{s}}{Y_{u}-Y_{s}} \text {. }
$$

12 The returns to work experience were, for instance, between 1.9 and 1.1 in Slovenia in 1987 and 1991 (Orazem and Vodopivec, 1997), between 3.1 and 2.1 in Poland from 1987 to 1993 (estimate based on household survey data, Rutkowski, 1996), slightly higher than 1 in Poland in 1996 (Adamchik and Bedi, 2000). The available literature on CIS countries provides a wide range of values for the annual return to work experience. In some cases, such as Russia, they were very low all over the 1990s. In other cases, they were high, but dramatically declined over the decade, as soon as market mechanisms started to come into play and seniority rules to weaken. In Kyrgyzstan, for instance, they fell from 5.2 in 1993 to 1.3 in 1997 (Anderson and Pomfret, 2000). 
Table 4 presents the results of augmented earnings equations by gender and year, controlling for some occupations, regional dummies (omitted from the table) and some other country specific variables, such as serving in the army, being disabled, being a housewife and being hit by the Chernobyl disaster. These last variables are almost unique of the available data set and deserve a particular attention.

\section{[Table 4 about here]}

Generally, household surveys exclude military servicemen from the sampling population. However, in the case of Belarus, such group was particularly important, as to its size and economic treatment within the state sector. Belarus was on the Western border of the former Soviet Union and, as a consequence, was always under alert at the time of the Cold War. Now, one of the most important aspects of transition was the process of demilitarisation. This involved not only a dramatic contraction of expenditure, but also a reduction in the number of people employed in the military sector. The estimates provide a measure of the impact of these phenomena on the wages of military personnel vis à vis the rest of paid workers.

The variable for disabled people has been added to provide evidence of the degree of their wage gap. The survey provides information on housewives. This can be thought of as a proxy for the hours worked by some housewives who are also salary earners.

Furthermore, Belarus was one of the countries most hit by the Chernobyl disaster. As a consequence, many people experienced unusual malformation and cancers. All over the 1990s, the Government provided a special subsidy to people hit by the disaster, though such subsidies were progressively, but drastically reduced in the second half of the 1990s. The dummy refers to individuals who declare that their health was seriously affected by the Chernobyl disaster. 
The baseline group in these regressions includes able men working in the budget sector, but not serving in the army, holding compulsory education and living in Minsk city. The focus is on monthly net income from the main job and on overall labour income, as the previous analysis has shown that other sources of income are attributed according to some compensating mechanism, perhaps based on equity considerations and centrally determined, rather than according to human capital considerations.

The goodness of fit of these estimates is more satisfactory. The Adj.- $\mathrm{R}^{2}$ increases remarkably compared to that found in the case of basic earnings equations, sometimes up to a hundred percent of the previous value, but remains quite low also compared to other transition economies, especially in CEE. Moreover, similar to Orazem and Vodopivec (1997), the analysis shows a decreasing goodness of fit in 2001. The Adj.- $\mathrm{R}^{2}$ reduces consistently by about 0.04 in all the estimates, giving the impression of an increased complexity of the production structure, which perhaps the available release of the BHSIE does not allow catching. As reported in the last row of Table 4, an F-test consistently rejects the null hypothesis that all the regressors additional to those in the basic earnings equation are jointly equal to zero.

The coefficients for educational qualifications shrink remarkably compared to those obtained in basic earnings equations, confirming that the variables added to this specification do affect returns to education. Obtaining a university degree provides its owner with a ceteris paribus increase in monthly wages from the main job by about $70 \%$ in 1996 and $75 \%$ in 2001 . This amounts to an annual rate of return to tertiary education of about 10.1 and $10.7 \%$, respectively, which is still remarkably higher than in other transition countries. One additional year of tertiary education after completing technical, vocational and general secondary school provides a return of 8,13 and $9.8 \%$. 
When looking at the return to secondary school attainment, one interesting result stands out. In the augmented version of the earnings equation, the annual rate of return to vocational education dramatically falls to about $6.3 \%$. The comparable figures for workers with technical secondary and general secondary education are 11.8 and $11 \%$. Experimenting with variables shows that the reduction in the return to vocational education mainly depends on the introduction of regional dummies. Dropping regional dummies implies an increase in the annual returns to vocational education to $10.3 \%$.

Similar observations apply to the overall level of wages. In 2001, two are the main differences, already noted analysing basic earnings equations: the slight general increase in the returns to post-compulsory education and the improvement for workers with vocational secondary attainment.

The coefficient for the years of work experience is stable at 5-6\% for each additional year of work experience, almost the same as that found in the basic earnings equations. Though, from 1996 to 2001 there seems to be an increase in the steepness of the earnings profile, whose maximum shift from 26.5 to 30 years.

The coefficient for the gender dummy is high and significant, suggesting that women have lower ceteris paribus wages, by about $17-18 \%$. The conditional gender pay gap is substantially stable across different types of estimates. Part of its effect is caught by the variable relative to housewives. All other factors constant, when this last variable is dropped, the gap rises to about $22 \%$.

The other typical discrimination coefficient, relative to disabled workers, is also significant, though slightly decreasing over the period considered. The wage from the main job of able people was about $170 \%$ in 1996 and $143 \%$ in 2001 higher than the median wage of the disadvantaged. This group was less discriminated when other 
sources of income are considered. Such sources of income provided the disabled workers with some sort of compensation.

It is interesting to note that the return to serving in the army, which was still very high in 1996 is dramatically shrinking in recent years. The wage premium of servicemen reduced from 84 to $35 \%$, mirroring the aforementioned process of country's demilitarisation. This is the only case when additional sources of income increase the return to those who already have higher wages.

Finally, there is the loss of earnings potential experienced by workers affected in some way by the Chernobyl disaster. This amounts to about $27 \%$ of the median wage of the baseline group in 1996 and to about $22 \%$ in 2001 . The wage gap dramatically shrinks when one considers all labour incomes, suggesting that subsidies and pensions tend to compensate this weak group. The compensation was much stronger in 1996, when the wage gap is cancelled, than in 2001, when it was only halved.

Young people, here defined as people aged 30 or below, are presented in a large anecdotal literature as the true winners of transition. The rational would be that, holding the educational level constant, young people possess fresh human capital formed during the new era, while older people's knowledge was formed previously and is not suitable anymore to the needs of the market economy. To test this hypothesis, a dummy for individuals aged under-30 was first included in the estimates. The coefficient was negative, but not significant in both the considered years. This is hardly surprising as young people earn universally lower wages as a compensation for their lack of work experience. As a further test, we interacted the dummy relative to young people with dummies representing various levels of education attainment. The results relative to 1996 seem to confirm the conclusion of the anecdotal literature: ceteris paribus, in fact, 
young people holding a university degree have a wage premium of about $17 \%$. This gap disappears when other educational groups are considered, for which the coefficient is not significant. In 2001, the advantage of young people with tertiary education dramatically reduces, with the coefficient becoming insignificant. Instead, a statistically significant youth wage premium appears for those with vocational (22.4) and general secondary (14.8) education.

\subsection{Returns to different types of university degrees}

Table 5 attempts to catch the ceteris paribus effect of different types of University degree. The estimates suggest that a process of convergence in the payoffs has taken place over the second half of the 1990s. The boom of economic specialisation, which happened immediately after starting the reforms led to an "overproduction" of economists, which in turn caused, most likely, a considerable decline of their premium and an increase in that to, say, engineers and pedagogues in 2001. In fact, the wage from the main job (Wage1) has almost tripled for the pedagogic staff over the five years considered. Considering that most educational institutions are still state owned, this result probably mirrors a state policy aimed at maintaining pedagogic personnel, which in fact was at the very bottom of the scale of returns in 1996. The increasing payoff to engineers was also to be expected, since after a sharp decline of production in the first half of the 1990s there was a turning point in 1996, when also GDP started to recover, mainly by means of reviving the industrial basis of the country.

It is interesting to note that the overall wage (W3) is much more equally distributed among different types of degrees, in both years considered. The comparison between men and women shows that the higher returns to education of women with a university 
degree is spread almost equally across all types of specialisation, with the exception of medicine, where the return is almost the same in 1996 and lower for women in 2001.

Overall, the process of equalising the premium to different University degrees could be interpreted as evidence of a high degree of efficiency of the University system to match workers with available jobs and / or of the presence of the state in determining wage-setting mechanisms.

\section{[Table 5 about here]}

\subsection{The gender wage gap}

Table 4 provides estimates of augmented earnings equations for men and women separately. As found in previous studies relative to other transition countries (Reilly, 1999; Orazem and Vodopivec, 1997; Brainerd, 2000; Anderson and Pomfret, 2000; Brainerd, 2000; Gerry, Kim and A Li, 2002), despite the high and persistent discrimination noted in the estimates relative to the entire sample, women tend to exhibit higher returns to education than men. The rate of return for any additional year of post-compulsory education equals 8.3 in 1996 and 9.3 in 2001 for men and 12.1 for women in both estimates. Women receive higher wages from their main job than men across all educational groups, though the gap tends to reduce for individuals holding a high secondary school diploma. The gender differences in returns to work experience are negligible in both years.

When one looks at the overall labour income, the returns to education of men become higher than those of women. This might suggest, on the one hand, that the central allocation of subsidies is discriminating women and, on the other hand, that men fare better than women in secondary jobs and entrepreneurial activities. 


\subsection{Sample selection bias}

Transition has been a period of dramatic structural change also in Belarus, causing the appearance of unemployment. There are reasons to believe that unemployment concentrated especially among low skill workers. This might tend estimates of earnings functions to be affected by sample selection, causing, in turn, an upward bias in the returns to education. In other words, the sample of paid workers could include a relatively larger share of skilled individuals compared to the population. To test for this hypothesis, we implement the Heckman (1979) correction model, using the Maximum Likelihood estimator $^{13}$.

The classical example of the Heckman correction procedure is that of the wage offers distribution of women. Focusing only on the earnings of the individuals who actually work will produce biased estimates, especially in the case of women, since, generally, their participation is lower than that of men. The basic intuition of Heckman (op. cit.) to explain the possible bias caused by sample selection is that the earnings equation is missing some variables able to explain the degree of participation of women. If one finds the factors affecting the participation of women, but not their wages, it is possible to estimate a specific equation, the so-called participation or selection equation, having as a dependent variable a dummy taking a value of one if an individual is employed and zero otherwise and, thus, obtain a measure of her probability to participate in the labour market (the inverse Mills ratio). Adding this last variable to the main equation, in this case the earnings equation, would provide a test of the existence

\footnotetext{
${ }^{13}$ The results do not dramatically change when implementing the Heckman two-step procedure.
} 
of sample selection bias and correct the coefficients in case the added variable proves to be significant. Analytically, model [1] consists now of two equations:

$$
\begin{aligned}
& y=\mathbf{X} \boldsymbol{\beta}+u, \text { with } E(u \mid x)=0 \\
& S=1 \text { if } z \gamma+v \geq 0
\end{aligned}
$$

where for simplicity sake the $\log$ wage is here called $y$, and $\mathbf{X}$ includes also the human capital variables. The main equation [2] is nothing else but the usual earnings equation and can be estimated by OLS. The selection equation [3] can be estimated by probit. Sample selection arises when there is correlation between $u$ and $v$. In this case, and assuming that $u$ is independent of $z$, the expected value of $y$, will be:

$$
E(y \mid z, v)=\mathbf{X}_{\mathbf{i}} \boldsymbol{\beta}+\rho \lambda(z \gamma)
$$

where $\rho$ is the correlation between the error terms of the main and of the participation equation and $\lambda$ is the inverse Mills ratio evaluated at $z \gamma$. This equation shows that when there is sample selection to obtain unbiased estimates of $\beta$, one should include the term $\lambda(z \gamma)$ as an additional regressor. In fact, if $\rho=0, \lambda(z \gamma)$ does not appear, and OLS will consistently estimate $\beta$. However, if $\rho$ is different form 0 , ignoring the $\lambda(z \gamma)$ term is equivalent to omitting significant variable, and the coefficients will be biased. The inverse Mills ratio can be estimated by probit in the first step and in the second step the correlation with the $y$ variable can be estimated by OLS. This method is sometimes called the Heckit for assonance with the Tobit model. In addition to this twostep procedure, the two equations above can be simultaneously estimated by maximum likelihood, as done in this study.

An important point to bear in mind is that the independent variables in the main equation, $x$, should be a strict subset of the independent variables in the selection 
equation, $z$. In other words, the selection equation should include all the variables contained in the main equation - since the explanatory variables in the main equation usually affect also the probability of selection through wages -, plus some additional variables which should be chosen in such a way that they affect participation, but not earnings. This is because otherwise there could be a high correlation between $\lambda$ and $x$, which would lead to multicollinearity in the main equation.

In this study, the Heckit is used to test for the stability of the discrimination coefficient and of the higher returns to education of women. As recent studies (see, for instance, Gosling, 2003 and the references therein) suggest, this finding might be due to sample selection mechanisms and ability bias, which, as noted also in Orazem and Vodopivec (1997), are particularly strong in transition countries, since, in the face of increasing unemployment and inactivity, if the most skilled women keep their job with a higher probability, this might give the fake impression of higher returns to education for women compared to men.

The base category of the participation variable includes not only the unemployed, but also the inactive population aged over-16. Table 6 shows that, apart from the explanatory variables common to the earnings equation, the participation equation includes a set of additional variables, which affect participation, but not earnings. The instruments are: having more than three children for women, being under-30 or having reached the retirement age (55 for women and 60 for men), living in rural areas and declaring to have bad health.

\section{[Table 6 about here]}

The $\chi^{2}$ statistics in the last row of Table 6 and the value of $\rho$ suggest that there is sample selection bias. As expected, people tend to participate more the bigger is the 
number of their years of schooling, whereas women, especially if housewives, and disabled people have lower participation rates. People living in rural areas have higher participation rates. This might depend on the lower reservation wage of peasants due to the availability of a family land plot and on the low labour productivity in agriculture. Similar to other transition countries, also in Belarus agriculture represents a reservoir of manpower. Having more than three children seems not to significantly reduce the participation of women, which mirrors the need of households to count on two sources of income to survive. In addition, as expected, also in Belarus the youngest and the oldest segments of the population have lower employment rates. Having bad health affects the labour market participation of men, but not that of women.

After correcting for sample selection bias, the returns to education are generally reduced by a certain amount though the corrected coefficients are still remarkably high for a transition country. The annual rate of return to post-compulsory education is around $8 \%$ for those who reached university education, while the annual return to work experience reduces to $3-4 \%$. The returns to education of women become lower than those of men in 1996, but not in 2001. The gender discrimination coefficient is stable.

\section{Discussion}

The main result of this enquiry on the private returns to human capital in Belarus over the second half of the 1990s is that education pays off. Workers with compulsory education only fare much worse than their counterparts with higher educational levels, whatever the adopted estimation method.

These results might appear surprising to those observers who are used to think of Belarus as the most gradualist transition country. Particularly surprising is the fact that 
the skill payoff was high already in 1996, when transition was still at an early stage in Belarus.

How to explain this result? Two concurrent, but not alternative hypotheses seem to be the most likely candidate for an explanation. On the one hand, it might be that a market for human capital is actually in place and effectively working. However, it is not clear whether this market is left to the free interaction between demand and supply. It might also be, on the other hand, that the government is playing some role in granting a wage premium to experienced workers with a higher level of educational attainment, perhaps to maintain consensus of the intellectual class and of the oldest segments of the population. The high return to work experience is another indicator of the gradual approach to reforms in Belarus. It suggests that the old system of scaling wages mainly according to seniority rules is still in place and that market mechanisms find it still hard to emerge in this field.

In fact, this conclusion could partly explain the high degree of wage inequality typical of many FSU countries, often noted in the literature (Atkinson and Micklewright, 1992; Newell and Reilly, 1999), while not being in contrast with the conclusion of Katz (1999), who claims that the returns to education were high, not low under the central planning system.

It was also typical of the old system, to use subsidies and other monies to compensate low-wage workers with compulsory educational attainment only or below. The results of the estimates relative to such subsidies confirm that they are attributed independent of human capital levels, as a kind of centralised compensating mechanism implemented for egalitarian purposes, knowing that the main income is designed in a way to provide a large wage premium to education and work experience. 
Another interesting finding is the remarkable improvement of the position of workers with technical and vocational education in the early 2000s. This could be taken as a proof of the fact that similar to other transition countries, Belarus is exposed to international competition, which is, in fact, pushing internal productions to move to traditional, labour intensive sectors, which are also those providing larger premiums to skilled manual workers.

\section{Concluding remarks}

The gradualist approach to economic transition would contribute to form the $a$ priori expectation that the rate of return to education in Belarus should be low and the profile of the returns to work experience flat, like they supposedly were under centralplanning. However, the enquiry conducted in this paper shows that the education payoff in Belarus was remarkably high, at about $10.1 \%$, already in the mid-1990s, and remains high in recent years. Moreover, the Belarusian labour market provided quite a high and stable premium to work experience, of about $5 \%$ per year. Such results are only slightly reduced when implementing sample selection correction procedures.

This finding suggests making a distinction between Belarus and other transition countries, which almost universally experienced lower returns to work experience, which dramatically further declined over transition, and lower returns to education, which were on the rise over the period of reforms. An explanation could be the continuing pervasive role of the state in controlling the tariff system and imposing traditional seniority rules in Belarus, a country where the private sector has still a negligible size. This paper suggests that the believe that returns to education were low 
under the previous system was perhaps ill-posed and that the socialist system had in place robust mechanisms to stimulate and reward human capital accumulation, not much different from that typical of market economies.

Acknowledgements. Earlier versions of this paper were presented at the XIV AISSEC and XVI EALE Conferences. We thank all seminar participants, especially Irina Denisova and Vera Adamchik. We also thank Francesca Bettio, Samuel Bowles, Byung-Yeong Kim, Andrew Newell and Barry Reilly for the useful comments. Alina Verashchagina gratefully acknowledges the CNR-NATO Outreach Fellowship programme, which allowed her to carry out this research at the Department of Theoretical and Applied Economics, University of Naples "Federico II". She thanks the Department for the kind hospitality. The usual disclaimer applies. 


\section{Appendix I}

Table A.1. Variables definition

\begin{tabular}{ll}
\hline Variable name & Definition \\
\hline Ln (Wage $n), n=1,2,3$ & The dependent variable is represented by the natural logarithm of \\
& different types of incomes. The figures are computed by the \\
& Ministry of Statistics as an average of the wage declared by the \\
& worker, taking into account the number of months for which he \\
& received a wage.
\end{tabular}

Wage1 Net monthly wages, measured as an average value during the year. According to the questionnaire, monthly wages incorporate "wages from the main job including subsidies, benefits and dividends after deducting payroll, other taxes and alimonies".

Wage $1^{*}$

Wage2

Wage3

Years of potential work experience $(\mathrm{PWE}) \quad=$ age - education -6 .

Postgraduate degree (candidate or doctor of $=1$, if candidate or doctor of science; $=0$, otherwise (equivalent on science; aspirantura and doctorantura);

\section{University degree}

Technical school

(Technical or specialised high secondary school; technikum);

Vocational education

(Vocational Secondary Education; PTU, proftechuchilishche);

General secondary education

(General Secondary Education; obshcheobrazovatelanaya shkola) ${ }^{\mathrm{a}}$

Compulsory education

(Low secondary school)

Primary education (nachalnaya shkola)
$=$ other subsidies from the main job that are not included in wages, plus in-kind payments from the main job.

$=$ wages from other jobs, plus payments from occasional jobs other than running a private business or farming the family land plot, plus income from entrepreneurial activity.

$=$ total monthly labour income. In other words, wage $1+$ wage $2+$ wage 3 , plus pensions, plus other types of incomes.

average to 20 years of schooling)

$=1$, if University degree; $=0$, otherwise (equivalent on average to 16 years of schooling)

$=1$, if diploma of technical secondary school; $=0$, otherwise (equivalent on average to 13 years of schooling)

$=1$, if diploma of vocational secondary school; $=0$, otherwise (equivalent on average to 12 years of schooling)

$=1$, if diploma of general secondary school; $=0$, otherwise (equivalent on average to 11 years of schooling).

$=1$, if diploma of basic school; $=0$, otherwise (equivalent on average to 9 years of schooling)

$=1$ if primary education; $=0$ otherwise (equivalent on average to 4 years of schooling)

Note: ${ }^{a}$ General secondary education includes also special types of secondary school: Gymnasium, Lyceum, Specialized schools. 


\section{Appendix II. The education system in Belarus}

The Belarusian education system has slightly changed compared to that at the time of the FSU. The main changes include: a) the increase in the years of compulsory education from 8 to 9 and of basic secondary education from 10 to $11 ; b$ ) the introduction of new types of high secondary diplomas; c) the introduction of private schools and universities.

As shown in Figure A.1, the current 11-year-of-school education system ${ }^{14}$ comprises three levels: primary school (nachalnaya shkola; 4 years, from the age of 6 until 10); basic or incomplete secondary school (nezakonchennoe srednee obrazovanie; plus 5 more years, from the age of 10 until 15); and general secondary school (obshcheobrazovatelanaya shkola; plus two final years, from the age of 15 until 17). At the end of the 9 years of the first two stages, namely primary and incomplete secondary school, that are also compulsory, graduates have three possibilities for high secondary school: a) general secondary school; b) vocational school (PTU, proftechuchilishche; 3 years, from the age of 15 until 18); or c) technical school (technikum, 4 years, from the age of 15 until 19).

The options $\mathrm{b}$ and $\mathrm{c}$ give certain specialization, increasing the chances to find gainful employment. In the meantime, vocational and technical degrees give also access to University education (vysshee obrazovanie). Conversely, general secondary education is conceived as an incomplete level of education and many who obtain this type of diploma go either to University or, if they cannot pass the entrance exam, to vocational or technical school. In this case, completion of high school requires attending

\footnotetext{
${ }^{14}$ The on-going reform of the education system in Belarus started in 1998 is to raise up to 12 the years of school education (Vetokhin and Stepanov, 1999).
} 
1 year for vocational and 2 years for technical school. After that, high school graduates can try again to access University.

After 5 years on average, University graduates can access post-graduate courses (aspirantura) leading after 3-4 years of research work to the title of Candidate of Sciences (PhD equivalent $)^{15}$. Recently, an intermediate 1-year Magistrate programme (Master equivalent) was introduced.

\section{[Figure A.1 about here]}

The share of private Universities was about $30 \%$ all over the second half of the 1990s. The share of students enrolled in private Universities dramatically increased from $1.7 \%$ in 1992 to almost $15 \%$ in 1998. A large and stable share ranging from 34 to $40 \%$ of students enrolled in the University were involved in distant learning (32-39\%) or evening (0.7-3.9\%) programmes, while working. Over $50 \%$ of students registered in private Universities are involved in distant learning programmes. These changes gave rise to a debate about changing the quality of education on offer.

\footnotetext{
${ }^{15}$ The highest in academic life is the degree of Doctor of Science, which is awarded for outstanding scientific results, mainly after many years of academic career.
} 
Figure A.1. The Belarusian education system

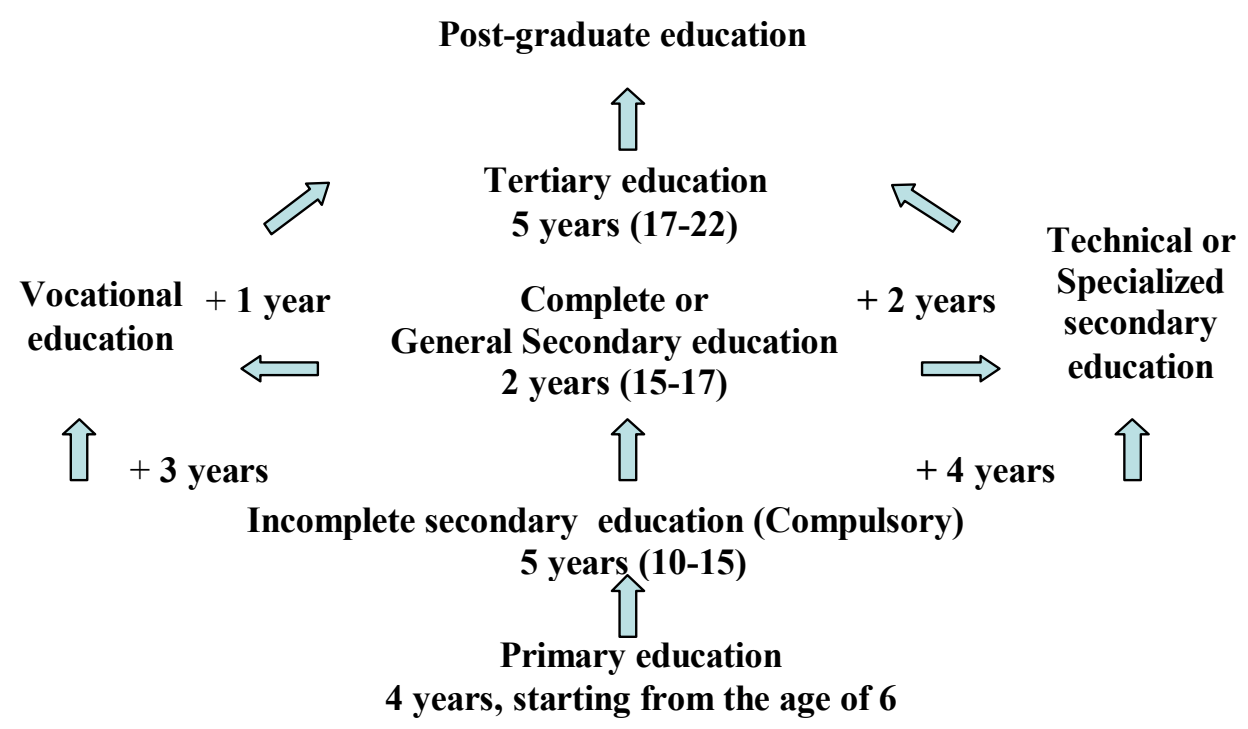




\section{References}

Adamchik, V.A., \& Bedi, A.S. (2000). Wage Differentials between the Public and the Private Sector: Evidence from an Economy in Transition. Labour Economics 7(2), 203-224.

Aghion, P., \& Commander, S. (1999). The Dynamics of Inequality in the Transition. Economics of Transition, special issue 7(2), pp. 275-298.

Anderson, K., \& Pomfret, R. (2000). Gender Effects of Transition: The Case of the Kyrgyz Republic. Adelaide University, Working Paper, 8.

Atkinson, A.B., \& Micklewright, J. (1992). Economic Transformation in Eastern Europe and the Distribution of Income. Cambridge University Press, Cambridge.

Benitez-Silva, H., \& Cheidvasser, S. (2000). The Educated Russian's Curse: Returns to Education in the Russian Federation. Yale University, Working Paper.

Brainerd, E. (2000). Women in Transition: Change in Gender Wage Differentials in Eastern Europe and FSU. Industrial and Labour Relations Review, 54(1), 139-162.

Clark, A. (2003). Returns to human capital investment in a transition economy. The case of Russia, 19941998. Interntional Journal of Manpower 24(1), 11-30.

Gerry, G., Kim, B-Y, \& Li, C. A (2002). The Gender Gap and Wage Arrears in Russia: Evidence from the RLMS. School of Slavonic and East European Studies, Working Paper, 24, June.

Gosling, A. (2003). The changing distribution of male and female wages 1978-2000: can the simple skills story be rejected?. CEPR, Discussion Paper, 4045.

Halvorsen, R. \& Palmquist, R. (1980). The Interpretation of Dummy Variables in Semilogarithimic Equations. American Economic Review 70(3), 474-75.

Heckman, J.J. (1979). Sample selection bias as a specification error. Econometrica 47(1), 153-62.

Katz, K. (1999). Where there no Returns to Education in the USSR? Estimates from Soviet Household Data. Labour Economics 6(3), 397-416.

Kornai J. (1992). The Socialist System. The Political Economy of Communism. Oxford, Oxford University Press.

Munich, D., Svejnar, J., \& Terrell, K. (2002). Returns to Human Capital under the Communist Wage Grid and during the Transition to a Market Economy. IZA Working paper, 122.

Newell, A. \& Reilly, B. (1999). Rates of Return to Education in the Transitional Economies. Education Economics 7(1), 67-84.

Orazem, P.F. \& Vodopivec, M. (1997). Value of Human Capital in Transition to Market: Evidence from Slovenia. European Economic Review 41(3-5), 893-903.

Psacharopoulos, G. (1994). Returns to Investment in Education: a Global Update. World Development 22(9), 1325-1343.

Reilly, B. (1999). The Gender Pay Gap over the Transition (1992-1996). The Economics of Transition $7(1), 245-254$.

Rutkowski, J. (1996). High skills pay-off: the changing wage structure during economic transition in Poland. Economics of Transition 4(1), 89-111.

Sabirianova, K.P. (2003). Skill-Biased Transition: The Role of Market, Institutions, and Technical Change. IZA Discussion Paper, 893, October.

Svejnar, J. (1999). Labour Markets in the Transitional Central and East European Economies. In: Ashenfelter, O. and Card, D. (pp. 2809-2857), Handbook of Labour Economics, vol. 3b, Ch. 42.

Trostel, P., Walker, I., \& Woolley, P. (2002). Estimates of the Economic Return to Schooling for 28 Countries. Labour Economics 9(1), 1-16.

Vetokhin, S., \& Stepanov, V. (1999). Education for All - 2000 Assessment. Basic Education in Belarus, Minsk.

Vaneev, D.I., Gurskiy, I.M., \& Kisel, E.C. (2001). Issledovanie rynka truda Belarsi. NII Truda, Minsk. 


\section{Annex of Tables}

Table 1. Employment, unemployment and retirement shares by educational level

\begin{tabular}{|c|c|c|c|c|c|c|}
\hline \multirow{3}{*}{ Education } & \multicolumn{2}{|c|}{ Employed } & \multicolumn{2}{|c|}{ Unemployed } & \multicolumn{2}{|c|}{ Pensioners } \\
\hline & 1996 & 2001 & 1996 & 2001 & 1996 & 2001 \\
\hline & \multicolumn{6}{|c|}{ All workers } \\
\hline Candidate or doctor of science & 0.5 & 0.3 & - & - & 0.0 & 0.3 \\
\hline University degree ( 5 years) & 17.9 & 20.4 & 8.5 & 7.8 & 6.5 & 7.8 \\
\hline Technical secondary education & 21.5 & 28.9 & 16.9 & 21.5 & 10.1 & 15.2 \\
\hline Vocational secondary education & 26.9 & 19.4 & 35.6 & 25.2 & 5.4 & 4.1 \\
\hline General secondary education & 23.0 & 25.8 & 26.4 & 36.5 & 7.3 & 13.2 \\
\hline Compulsory education or below & 10.3 & 5.2 & 12.6 & 9.0 & 70.6 & 59.3 \\
\hline \multirow{2}{*}{ Total } & 6459 & 6659 & 644 & 488 & 2742 & 2760 \\
\hline & \multicolumn{6}{|c|}{ Men } \\
\hline Candidate or doctor of science & 0.7 & 0.5 & - & - & - & 0.7 \\
\hline University degree ( 5 years) & 16.3 & 18.5 & 9.2 & 8.4 & 10.3 & 11.0 \\
\hline Technical secondary education & 15.1 & 22.6 & 12.3 & 18.1 & 8.6 & 14.6 \\
\hline Vocational secondary education & 30.9 & 22.5 & 37.0 & 26.4 & 7.6 & 5.9 \\
\hline General secondary education & 24.5 & 29.5 & 25.6 & 36.5 & 6.7 & 12.9 \\
\hline Compulsory education or below & 12.5 & 6.4 & 15.9 & 10.7 & 66.8 & 55.0 \\
\hline \multirow[t]{2}{*}{$\begin{array}{c}\text { Total } \\
\end{array}$} & 3215 & 3181 & 359 & 299 & 871 & 919 \\
\hline & \multicolumn{6}{|c|}{ Women } \\
\hline Candidate or doctor of science & 0.3 & 0.1 & - & - & 0.1 & 0.2 \\
\hline University degree ( 5 years) & 19.4 & 22.1 & 7.7 & 6.9 & 4.8 & 6.2 \\
\hline Technical secondary education & 27.8 & 34.5 & 22.8 & 27.0 & 10.8 & 15.5 \\
\hline Vocational secondary education & 22.8 & 16.6 & 33.7 & 23.3 & 4.4 & 3.3 \\
\hline General secondary education & 21.5 & 22.5 & 27.4 & 36.5 & 7.6 & 13.4 \\
\hline Compulsory education or below & 8.1 & 4.2 & 8.4 & 6.3 & 72.3 & 61.5 \\
\hline Total & 3244 & 3478 & 285 & 189 & 1871 & 1841 \\
\hline
\end{tabular}

Source: elaboration on the BHSIE. 
Table 2. Wages by educational levels, entire sample

\begin{tabular}{|c|c|c|c|c|c|c|c|c|}
\hline Educational levels & Wage1 & $\mathrm{I}$ & $\begin{array}{c}\text { Wage }{ }^{*} \\
(\% \text { of Wage } 1)\end{array}$ & $\mathrm{I}$ & $\begin{array}{c}\text { Wage } 2 \\
(\% \text { of Wage } 1)\end{array}$ & $\mathrm{I}$ & $\begin{array}{c}\text { Wage } 3 \\
(\% \text { of Wage } 1)\end{array}$ & $\mathrm{I}$ \\
\hline \multicolumn{9}{|l|}{1996} \\
\hline Doctorate & 1524.0 & 290 & $96.0(6.3)$ & 174 & $857.1(56.2)$ & 186 & $1908(125.2)$ & 331 \\
\hline University degree & 1272.2 & 242 & $93.5(7.4)$ & 145 & $684.6(53.8)$ & 148 & $1309.9(103.0)$ & 227 \\
\hline Technical secondary & 946.2 & 180 & $93.1(9.8)$ & 144 & $625.8(66.1)$ & 136 & $956.7(101.1)$ & 166 \\
\hline Vocational secondary & 818.9 & 156 & $88.0(10.8)$ & 137 & $563.1(68.8)$ & 122 & $853.0(104.2)$ & 148 \\
\hline General secondary & 768.0 & 146 & $72.9(9.5)$ & 113 & $562.0(73.2)$ & 122 & $808.9(105.3)$ & 140 \\
\hline Low secondary or below & 525.9 & 100 & $64.5(12.3)$ & 100 & $461.8(87.8)$ & 100 & $576.5(109.6)$ & 100 \\
\hline Total Nobs & 6452 & & 810 & & 752 & & 9544 & \\
\hline \multicolumn{9}{|l|}{2001} \\
\hline Doctorate & 156956.3 & 370 & $4750.0(3.0)$ & 174 & $17839.8(11.4)$ & 109 & $157293.8(100.2)$ & 298 \\
\hline University degree & 111374.4 & 262 & $5317.6(4.8)$ & 195 & $64780.6(58.2)$ & 396 & $114169.1(102.5)$ & 217 \\
\hline Technical secondary & 80728.6 & 190 & $5145.2(6.4)$ & 189 & $42813.7(53.0)$ & 262 & $82107.3(101.7)$ & 156 \\
\hline Vocational secondary & 77235.5 & 182 & $4191.2(5.4)$ & 154 & $50166.6(65.0)$ & 307 & $78950.4(102.2)$ & 150 \\
\hline General secondary & 67555.5 & 159 & $4300.6(6.4)$ & 158 & $44957.9(66.5)$ & 274 & $68883.6(102.0)$ & 131 \\
\hline Low secondary or below & 42441.7 & 100 & $2723.7(6.4)$ & 100 & $16361.9(38.6)$ & 100 & $52708.0(124.2)$ & 100 \\
\hline Total Nobs & 6349 & & 724 & & 599 & & 9312 & \\
\hline
\end{tabular}

Note:

${ }^{a}$ For the definition of variables see Table Al in the Appendix. Notice that the number of those receiving Wage 2 includes also individuals receiving unemployment benefits, pensions and so on.

$b$ " $I$ " represents the index of wages of each educational group relative to that of workers with compulsory education or below $(=100)$.

${ }^{c}$ The figures between brackets measure the ratio of the overall labour income and the earnings from the main job (Wage2/Wage1).

${ }^{d}$ On January 1, 2000 the Belarusian rouble was devalued (1:1000). All figures for the year 1996 are given in thousands of Belarusian roubles (BYR), instead for the year 2001 in "new" Belarusian roubles.

e According to the National Bank of the Republic of Belarus, the official exchange rate was: at the beginning of 1996, 11.5 thousands BYR/USD; at the end of 1996, 15.5 thousands BYR/USD (the average of the year was equal to 13.3 thousands BYR/USD); at the beginning of 2001it was $1180 \mathrm{BYR} / \mathrm{USD}$, and at the end of 2001 it was 1580 BYR/USD (the average of the year was 1390 BYR/USD).

Source: elaboration on the BHSIE. 
Table 3. Basic earnings functions

\begin{tabular}{|c|c|c|c|c|c|c|c|c|}
\hline & \multicolumn{4}{|c|}{1996} & \multicolumn{4}{|c|}{2001} \\
\hline & Wage 1 & Wage1* & Wage 2 & Wage3 & Wage 1 & Wage1* & Wage 2 & Wage3 \\
\hline Doctorate & 1.02 & 0.78 & 0.97 & 1.15 & 1.34 & $0.56 \dagger$ & $0.19 \dagger$ & 1.13 \\
\hline University degree & 0.88 & 0.32 & 0.42 & 0.86 & 0.93 & 0.54 & 0.72 & 0.82 \\
\hline Technical secondary & 0.56 & $0.36^{* *}$ & $0.35 \dagger$ & 0.50 & 0.59 & $0.43^{* *}$ & $0.55^{*}$ & 0.47 \\
\hline Vocational secondary & 0.30 & $0.30^{* *}$ & $0.08 \dagger$ & 0.33 & 0.49 & $0.35^{*}$ & $0.61^{\text {** }}$ & 0.41 \\
\hline General secondary & 0.29 & $0.12 \dagger$ & $0.15 \dagger$ & 0.30 & 0.35 & $0.40^{* *}$ & $0.54^{*}$ & 0.25 \\
\hline PWE & 0.052 & $-0.0002 \dagger$ & 0.030 & 0.030 & 0.05 & 0.03 & $0.033^{* *}$ & 0.028 \\
\hline $\mathrm{PWE}^{\wedge} 2$ & -0.001 & $-0.0002 \dagger$ & -0.001 & -0.0003 & -0.001 & -0.001 & -0.001 & -0.003 \\
\hline Cons & 5.55 & 3.89 & 5.13 & 5.68 & 9.93 & 7.10 & 9.24 & 10.20 \\
\hline Nobs & 6454 & 810 & 752 & 9546 & 6349 & 724 & 599 & 9312 \\
\hline $\mathrm{R}^{2}$ & 0.15 & 0.04 & 0.06 & 0.15 & 0.14 & 0.02 & 0.09 & 0.13 \\
\hline Adj.- $\mathrm{R}^{2}$ & 0.15 & 0.03 & 0.05 & 0.15 & 0.14 & 0.01 & 0.08 & 0.13 \\
\hline
\end{tabular}

Note:

${ }^{a}+$ not significant; $*$ significant at $10 \%$,**-significant at $5 \%$, if no mark-significant at $1 \%$.

${ }^{b}$ PWE means potential work experience. See Table Al in Appendix I.

${ }^{c}$ The Huber/White/sandwich estimator of variance is used to correct for heteroskedasticity.

Source: elaboration on the BHSIE. 
Table 4. Augmented earnings equations

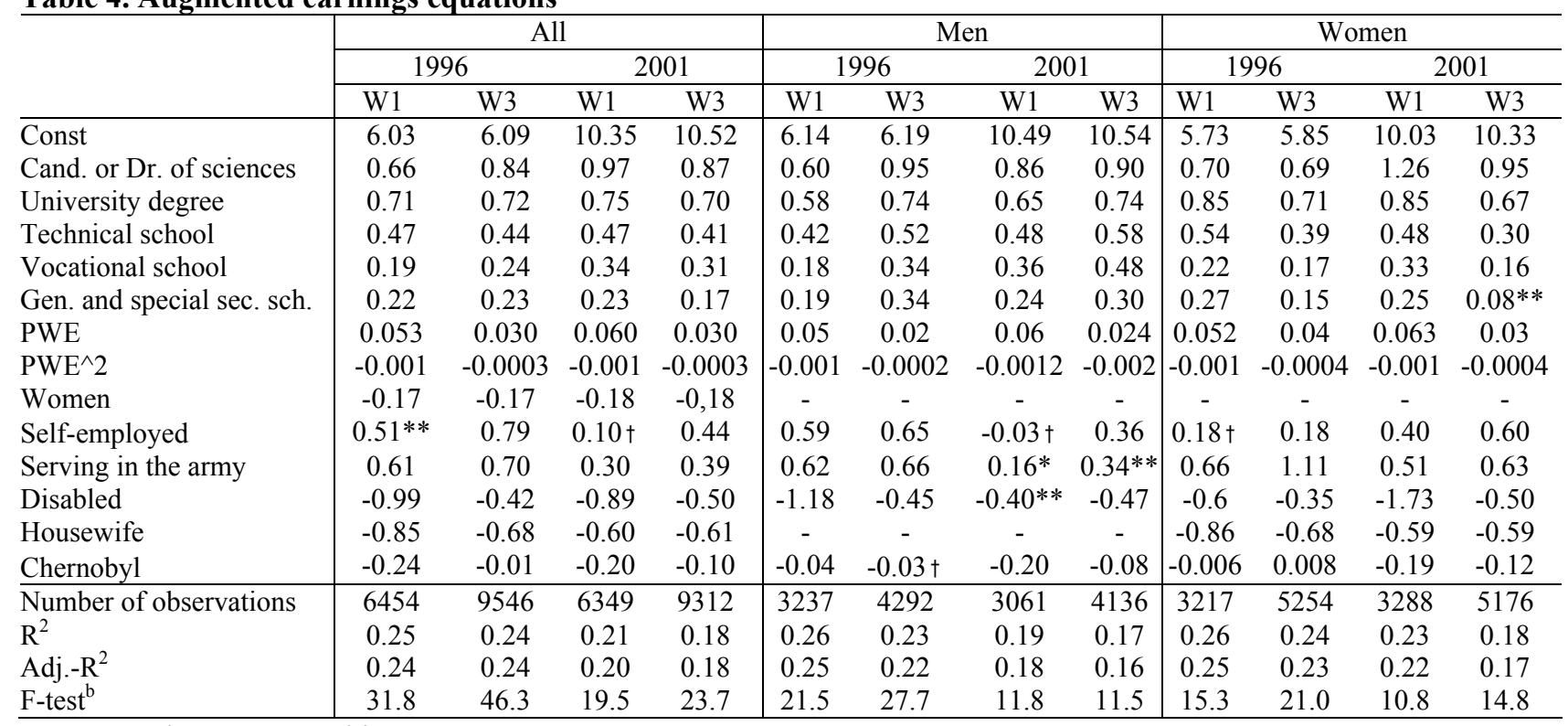

Note: See the notes to Table 3.

${ }^{a}$ Nineteen regional dummies were also included, but not reported. The dummies are obtained dividing each of the six existing oblasts into three sub-regions, relative to areas with large cities, small cities and rural areas. The baselines are compulsory education and Minsk city.

${ }^{b}$ The $H_{0}$ hypothesis of the F-test is that all the regressors additional to those in the basic earnings equation are jointly equal to zero.

Source: elaboration on the BHSIE. 
Table 5. Returns to a specific university degree

\begin{tabular}{l|cccc|ccccc|ccc|c|}
\hline \multirow{2}{*}{} & \multicolumn{4}{|c|}{ All } & \multicolumn{4}{c|}{ Men } & \multicolumn{4}{c|}{ Women } \\
\cline { 2 - 13 } & \multicolumn{3}{|c|}{1996} & \multicolumn{2}{|c|}{2001} & W96 & 2001 & \multicolumn{3}{c|}{1996} & 2001 \\
\cline { 2 - 12 } & W1 & W3 & W1 & W3 & W1 & W3 & W1 & W3 & W1 & W3 & W1 & W3 \\
\hline Economics & 0,79 & 0.84 & 0.66 & 0.67 & 0.63 & 0.71 & 0.43 & 0.58 & 0.90 & 0.88 & 0.79 & 0.67 \\
Medicine & 0.95 & 0.84 & 0.75 & 0.72 & 1.04 & 1.04 & 0.84 & 0.90 & 0.97 & 0.77 & 0.76 & 0.64 \\
Engineering & 0.68 & 0.72 & 0.77 & 0.71 & 0.60 & 0.75 & 0.73 & 0.76 & 0.78 & 0.68 & 0.84 & 0.70 \\
Natural sciences & 0.66 & 0.72 & 0.82 & 0.63 & 0.53 & 0.86 & 0.44 & 0.49 & 0.77 & 0.63 & 1.08 & 0.71 \\
Humanitarian sciences & 0.71 & 0.75 & 0.79 & 0.72 & 0.67 & 0.92 & 0.66 & 0.70 & 0.78 & 0.65 & 0.92 & 0.74 \\
Pedagogic & 0.27 & 0.75 & 0.86 & 0.78 & 0.72 & 0.76 & 0.79 & 0.89 & 0.89 & 0.72 & 0.91 & 0.70 \\
Military school & 0.27 & 0.616 & 0.523 & 0.66 & 0.20 & 0.66 & 0.49 & 0.75 & 0.63 & 0.63 & - & - \\
Agriculture & 0.58 & 0.53 & 0.56 & 0.52 & 0.47 & 0.61 & 0.56 & 0.67 & 0.80 & 0.48 & 0.57 & 0.40 \\
\hline
\end{tabular}

Note: See the Notes to Table 3. The estimates contain all the variables as in Table 4.

Source: elaboration on the BHSIE. 
Table 6. Augmented earnings equations correcting for sample selection bias.

\begin{tabular}{|c|c|c|c|c|c|c|c|c|c|c|c|c|}
\hline & \multirow{2}{*}{\multicolumn{4}{|c|}{ All }} & \multirow{2}{*}{\multicolumn{4}{|c|}{ Men }} & \multirow{2}{*}{\multicolumn{4}{|c|}{ Women }} \\
\hline & & & & & & & & & & & & \\
\hline & \multicolumn{2}{|c|}{1996} & \multicolumn{2}{|c|}{2001} & \multicolumn{2}{|c|}{1996} & \multicolumn{2}{|c|}{2001} & \multirow{2}{*}{$\begin{array}{c}1996 \\
\text { W1 }\end{array}$} & \multicolumn{3}{|c|}{2001} \\
\hline & W1 & W3 & W1 & W3 & W1 & W3 & W1 & W3 & & W3 & W1 & W3 \\
\hline Const & 6.68 & 6.48 & 11.24 & 11.18 & 6.76 & 6.60 & 11.42 & 11.25 & 0.54 & 5.90 & 10.83 & 10.93 \\
\hline Cand. or Dr. scienc. & 0.53 & 0.79 & 0.64 & 0.87 & 0.52 & 0.91 & 0.52 & 0.76 & 0.62 & 0.68 & 0.90 & 1.07 \\
\hline University degree & 0.52 & 0.58 & 0.45 & 0.50 & 0.43 & 0.58 & 0.32 & 0.50 & 0.33 & 0.69 & 0.61 & 0.50 \\
\hline Technical school & 0.29 & 0.33 & 0.17 & 0.23 & 0.28 & 0.37 & $0.09 \dagger$ & 0.30 & 0.09 & 0.37 & 0.30 & 0.16 \\
\hline Vocational school & $0.07 *$ & 0.17 & $0.07 \dagger$ & 0.18 & $0.08 \dagger$ & 0.21 & $-0.01 \dagger$ & 0.27 & $0.15 \dagger$ & 0.16 & $0.18 * *$ & 0.08 * \\
\hline $\begin{array}{l}\text { Gen. Second. } \\
\text { school }\end{array}$ & 0.10 & 0.17 & $0.04 \dagger$ & 0.10 & $0.08 \dagger$ & 0.23 & $-0.02 \dagger$ & 0.18 & 0.03 & 0.14 & 0.13 * & $0.03 \dagger$ \\
\hline PWE & 0.03 & 0.02 & 0.04 & 0.01 & 0.03 & 0.01 & 0.03 & 0.01 & -0.001 & 0.03 & 0.04 & 0.02 \\
\hline $\mathrm{PWE}^{\wedge} 2$ & -0.001 & -0.001 & -0.001 & -0.001 & -0.001 & -0.001 & -0.001 & -.0001 & -0.001 & -0.001 & -0.001 & -0.001 \\
\hline Women & -0.16 & -0.16 & -0.21 & -0.19 & - & - & - & - & - & - & - & \\
\hline Self-employed & 0.54 & 0.80 & 0.13 & 0.45 & 0.59 & 0.67 & $0.08 \dagger$ & 0.40 & $0.34 \dagger$ & 1.10 & 0.28 * & 0.58 \\
\hline Serving in the army & 0.50 & 0.64 & 0.18 & 0.30 & 0.50 & 0.61 & 0.16 * & 0.25 & 0.52 * & 0.75 & $0.37 \dagger$ & $0.53 * *$ \\
\hline Disabled & $0.12 \dagger$ & -0.35 & 0.42 & -0.42 & $-0.04 \dagger$ & -0.42 & 0.69 & -0.40 & 0.36 * & -0.34 & $-0.32 \dagger$ & -0.42 \\
\hline Housewife & $-0.06 \dagger$ & -0.34 & -0.62 & $-0.004 \dagger$ & & & & & $-0.05 \dagger$ & -0.64 & 0.32 & $-0.07 \dagger$ \\
\hline Chernobyl & $-0.02 \dagger$ & $-0.01 \dagger$ & -0.12 & -0.10 & $-0.03 \dagger$ & $-0.03 \dagger$ & -0.08 * & -0.08 * & $-0.001 \dagger$ & $0.01 \dagger$ & -0.15 & -0.12 \\
\hline Log L'd & -2830.8 & -12911.9 & -9873.6 & -14071.4 & -4798.1 & -6068.6 & -4839.6 & -6467.77 & -4743.09 & -6717.15 & -4987.05 & -7515.55 \\
\hline Nobs & 7419 & 10805 & 7535 & 11079 & 3618 & 4821 & 3589 & 4896 & 3801 & 5984 & 3946 & 6183 \\
\hline \multicolumn{13}{|c|}{ Participation equation } \\
\hline Cosnt & $-0.54 \dagger$ & -2.83 & $-0.67 \dagger$ & -3.35 & -1.18 & -3.56 & $-1.20 *$ & -2.77 & $0.04 \dagger$ & $-1.61 * *$ & $0.24 \dagger$ & -4.15 \\
\hline Years of education & 0.26 & 0.63 & 0.23 & 0.65 & 0.35 & 0.73 & 0.30 & 0.55 & $0.16 \dagger$ & 0.42 & $0.100 \dagger$ & 0.78 \\
\hline Years $\mathrm{c}$ & -0.01 & -0.02 & -0.01 & -0.02 & -0.013 & -0.03 & -0.01 & -0.02 & $-0.01 \dagger$ & -0.01 & $-0.004 \dagger$ & -0.03 \\
\hline Women & -0.16 & -0.16 & $-0.05 \dagger$ & -0.12 & - & - & - & - & - & - & - & - \\
\hline Disal & -1.84 & $-0.27 *$ & -1.70 & $-0.18 \dagger$ & -1.72 & -0.09 & -1.70 & -0.15 & -2.00 & -0.55 & -1.797 & $-0.16 \dagger$ \\
\hline Hous & -1.12 & -0.87 & -0.89 & -0.95 & - & - & - & - & -1.07 & -1.02 & -1.014 & -1.04 \\
\hline $\begin{array}{l}\text { More than three } \\
\text { children }\end{array}$ & $-0.11 \dagger$ & $0.18^{*}$ & $-0.05 \dagger$ & 0.11 * & - & - & - & - & $-0.14 \dagger$ & $0.15 \dagger$ & $-0.123 \dagger$ & 0.22 ** \\
\hline Aged 16 to 30 & -0.39 & -0.80 & -0.19 & -0.54 & -0.33 & -0.78 & -0.18 & -0.44 & -0.40 & -0.97 & -0.247 & -0.65 \\
\hline Over- $55^{\mathrm{a}}$ & $-0.08 \dagger$ & 0.26 & $0.08 \dagger$ & 0.25 & $-0.27 * *$ & 0.30 & $0.10 \dagger$ & 0.23 & $-0.05 \dagger$ & 0.50 & $-0.046 \dagger$ & 0.31 \\
\hline Rural & 0.16 & 0.20 & 0.18 & 0.20 & 0.23 & 0.26 & 0.19 & 0.24 & 0.08 * & 0.18 & 0.171 & 0.16 \\
\hline Bad health & -0.12 & $-0.07 \dagger$ & -0.14 & -0.04 & -0.16 ** & $-0.15 * *$ & -0.20 & -0.10 * & $-0.09 \dagger$ & $0.02 \dagger$ & $-0.065 \dagger$ & $-0.01 \dagger$ \\
\hline$\overline{\text { Rho }}$ & -0.9257 & -0.7818 & -0.9698 & -0.9227 & -0.91685 & -0.7896 & -0.9781 & -0.9511 & -0.93877 & -0.1293 & -0.9531 & -0.8911 \\
\hline Sigma & 0.8585 & 0.7280 & 0.9209 & 0.8377 & 0.8748 & 0.7813 & 0.9662 & 0.8982 & 0.834276 & 0.6226 & 0.8642 & 0.7794 \\
\hline Lambda & -0.7947 & -0.5691 & -0.8931 & -0.7729 & -0.8020 & -0.6169 & -0.9451 & -0.8542 & -0.7832 & -0.0805 & -0.8237 & -0.6945 \\
\hline Chi2(1) $($ rho $=0)$ & 347.31 & 56.92 & 1034.04 & 714.98 & 185.09 & 56.64 & 566.63 & 395.67 & 145.08 & 5.75 & 442.46 & 313.90 \\
\hline
\end{tabular}

Note: See the Notes to Table 4.

"In the case of men, the variable becomes "over-60", which is the retirement age.

Source: elaboration on the BHSIE. 